RU Мотивы и ценности студентов, выбравших педагогическую профессию

Полковникова Н. Б.

Аннотация. Цель исследования - выявление корреляции ценностных ориентаций личности и мотивов выбора педагогической профессии студентами. В статье даны теоретическое обоснование и анализ исследований по проблеме соотношения мотивов и ценностей в выборе педагогической профессии, представлены результаты эмпирического исследования мотивационно-ценностной сферы личности студентов педагогического вуза. Научная новизна исследования состоит в выявлении особенностей структуры личности молодых людей, выбравших педагогическую профессию. В результате исследования доказано, что высокая степень корреляции мотивов выбора педагогической профессии и ценностей личности выявлена в направленности на взаимодействие с людьми и в направленности на себя.

\title{
Motives and Values of Students - Future Teachers
}

Polkovnikova N. B.

\begin{abstract}
The study aims to determine correlation between a person's value system and motives for choosing the teaching profession. The article provides theoretical rationale and analysis of scientific papers on the issue of correlation between motives and values in choosing the teaching profession, presents results of an empirical study of the motivational-value sphere of teacher education students' personalities. Scientific novelty of the study lies in identifying specific features of the personality structure of young people who have chosen the teaching profession. As a result of the research, it is proved that there is a high degree of correlation between motives for choosing the teaching profession and a person's values in orientation towards interaction with people and orientation towards self.
\end{abstract}

\section{Введение}

Актуальность исследования. В педагогике последних десятилетий прослеживается интерес к вопросам становления личности. Тематика научных исследований раскрывает проблемы ценностных ориентаций личности и мотивы деятельности и поведения молодых людей $[2-4 ; 7 ; 9 ; 11 ; 14 ; 16 ; 17 ; 19 ; 21 ; 24]$. Личностный выбор, который они совершают, напрямую связан с изменениями в их собственной жизни. Профессиональное самоопределение - одна из наиболее важных проблем, стоящих перед молодыми людьми. Выбор профессии обусловлен значительным числом внешних и внутренних факторов, которые требуют изучения. В этой области наибольшую значимость, на наш взгляд, имеет исследование связи мотивов и ценностей профессионального выбора будущих педагогов, так как от них в значительной мере зависит, каким станет будущее общества и государства.

\section{Задачи исследования:}

- проанализировать теоретические подходы к изучению связей личностных ценностей субъекта с его мотивацией;

- исследовать мотивы профессионального выбора и ценностные ориентации студентов педагогического университета;

- выявить связи ценностных ориентаций личности и мотивов выбора профессии в структуре личности студентов педагогического университета.

Методы исследования. Теоретические методы: анализ, синтез, абстрагирование; эмпирические методы: проективные методики (анкета с открытыми вопросами «Мой выбор педагогической профессии», эссе «Почему я выбрала педагогическую профессию») и стандартизованные методики («Опросник ценностей» Рокича, опросник Шварца; «Тест смысложизненных ориентаций» Д. А. Леонтьева); метод измерения.

Теоретическая база исследования представлена концепцией культурно-исторического развития психики Л. С. Выготского [6]; положениями о сущности личности в трудах Б. Г. Ананьева [1], А. Н. Леонтьева [10], 
С. Л. Рубинштейна [15]; представлениями о ценностных ориентациях личности как о вершине иерархической системы предрасположенностей человека в концепции диспозиционной регуляции социального поведения личности В. А. Ядова [20].

Практическая значимость обусловлена тем, что использование результатов исследования повысит эффективность проектирования и реализации образовательного процесса вуза, будет способствовать росту профессиональной мотивации студентов в ходе обучения.

\section{Анализ теоретических подходов к изучению связей личностных ценностей субъекта с его мотивацией}

Классическая психология анализирует социальную опосредованность личностных ценностей с опорой на концепцию культурно-исторического развития личности Л. С. Выготского [6]. Одним из путей самоидентификации человека с социумом является соотнесение систем индивидуальных и общественных ценностей, их согласованность. Это важный аспект развития личности.

Проблема ценностей личности и социальных ценностей раскрывается в особом видении понятия «личность». Разные научные взгляды объединяет признание направленности в качестве ведущей характеристики личности. Данная позиция раскрывается ведущими отечественными учёными: Б. Г. Ананьевым [1], А. Н. Леонтьевым [10], С. Л. Рубинштейном [15] и другими с помощью различных представлений о сущности личности (Рисунок 1). Направленность представляет собой системообразующее свойство, которое определяет психический склад личности. В направленности проявляются все психические свойства личности: мотивация, ценностные ориентации, потребности, убеждения, интересы и прочее. Фундаментом направленности личности служит потребностно-мотивационная сфера, которая формирует жизненные цели человека.

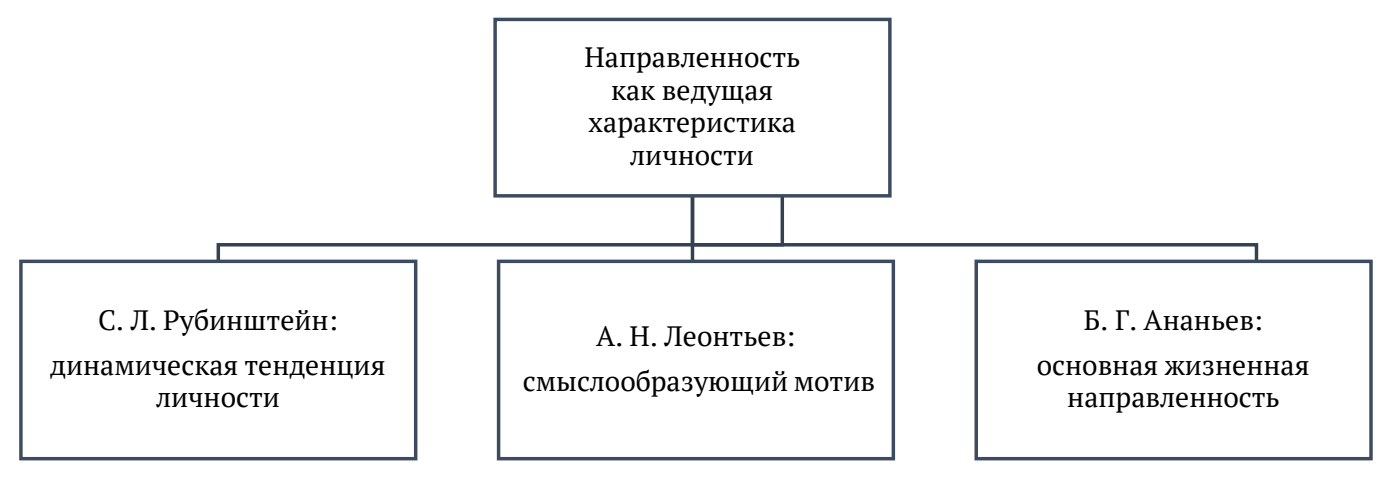

Рисунок 1. Представления о сущности личности ведущих отечественных учёных

С. Л. Рубинштейн [Там же] развивает мысль о том, что ценности - это производное соотношений социального мира и человека. Они отражают то, что важно, значимо для человека и общества. Системно-деятельностный подход А. Н. Леонтьева [10] рассматривает ядро личности через призму иерархии мотивов. Эта иерархия порождается системой общественных отношений, в которые вступает человек в деятельности. По мнению Б. Г. Ананьева [1], индивидуальная характеристика личности напрямую зависит от социального статуса человека. Социальный статус определяет роли, которые человек принимает на себя, и личностные ценности, которые складываются в социальной среде. Социальный статус, социальные роли и личностные ценности детерминируют характер, склонности и свойства личности, определяют её поведение.

В концепции диспозиционной регуляции социального поведения личности В. А. Ядова [20] ценностные ориентации представлены в качестве вершины иерархической системы предрасположенностей человека. Ценности личности прямо зависят от ценностей общества, в котором живёт и с которым идентифицирует себя человек (Рисунок 2).

Сегодня внимание большого числа исследователей сконцентрировано вокруг проблем формирования профессионального педагогического сообщества, повышения качества работы сотрудников сферы образования. Научные интересы А. Г. Асмолова [2, с. 48], В. И. Слободчикова [16, с. 1] и других определяются поиском механизмов и путей эффективной подготовки педагогов для разных уровней сферы образования.

Одно из направлений исследований личностных ценностей связано с утверждением сознания и самосознания как важного показателя становления личности. В этом ключе Г. Л. Будинайте и Т. В. Корнилова [4, с. 99] рассматривают ценности в системе других компонентов личности. Личностные ценности регулируют деятельность человека, в том числе профессиональную. По мнению исследователей, они концентрируются в области пересечения мотивов и потребностей личности и её мировоззрения.

Значимым шагом на жизненном пути личности служит профессиональное самоопределение, направленное на начало собственной трудовой деятельности, которая делает человека материально независимым. Профессиональное самоопределение требует большой внутренней работы, способности самостоятельно мыслить, осознания собственных мотивов, углублённого самопознания, адекватной самооценки. 


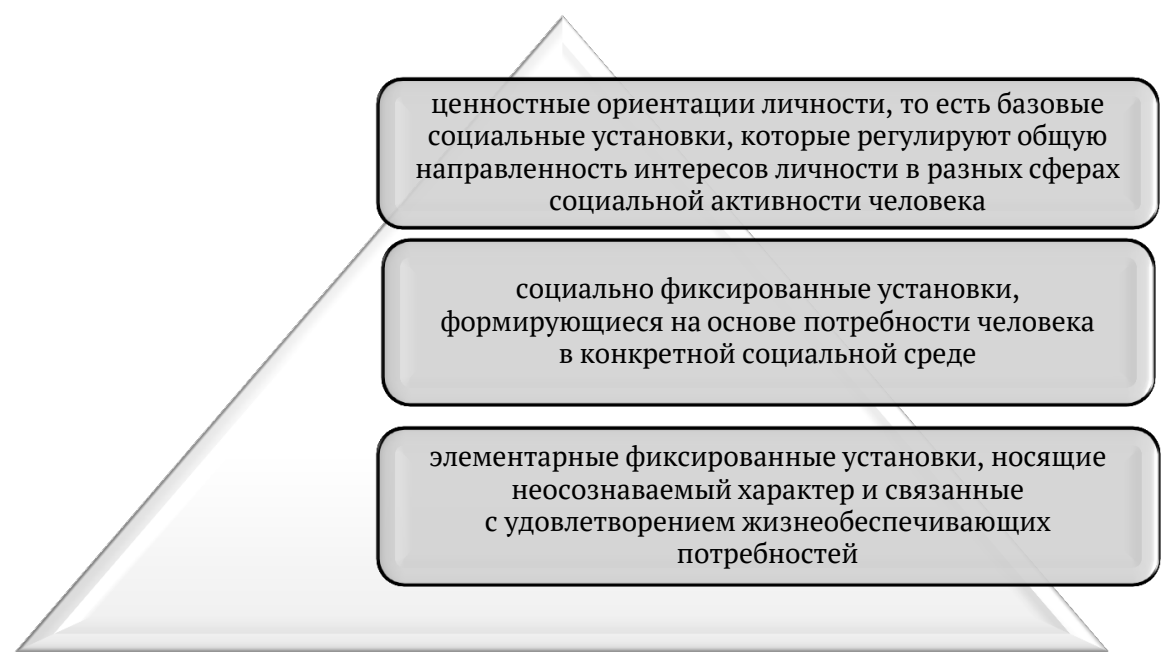

Рисунок 2. Структура личности в диспозиционной концепции регуляции социального поведения личности

Как отмечает Д. А. Леонтьев [11], интегральная характеристика личностной зрелости - это её личностный потенциал. Ценностные ориентации, цели и планы обеспечивают субъективную саморегуляцию жизни человеком, осознанное видение своих жизненных перспектив. Если ценностные ориентации не согласованы, личность испытывает затруднения в осуществлении выбора в значимых сферах жизни, например, в профессиональной. Недостаточно сформированная иерархия ценностных ориентаций или их конкуренция говорят об ограниченности личностного развития, порождают ситуацию неопределённости жизненного выбора.

Профессиональное становление личности осуществляется в ходе общения и деятельности человека. Развитие личности сопровождается изменением личностных отношений и изменениями в их структуре, выстраиванием иерархии ценностей и мотивов. Таким же образом формируется профессиональное сознание будущего педагога. В этом контексте проведены исследования А. Р. Фонарёва [19]; Н. Б. Полковниковой [26]; И. М. Реморенко, Б. Д. Эльконина, К. А. Баранникова, Е. В. Чудиновой, А. Г. Асмолова, П. Г. Нежнова и других [8]; В. С. Собкина, А. И. Андреевой и Ф. Р. Рзаевой [17]; В. А. Иванникова, А. Н. Гусева и Д. Д. Барабанова [9]; А. И. Подольского и О. А. Идобаевой [14]; J. Moate, M. Ruohotie-Lyhty [25]; A. Stellmacher, S. Ohlemann, J. Pfetsch, A. Ittel [27].

В последние десятилетия вокруг проблематики ценностей концентрируется внимание учёных, исследующих образовательную сферу. Среди них можно отметить труды С. Н. Гаврова и Н. Д. Никандрова [7]; Д. И. Фельдштейна [18]; Б. М. Бим-Бада [3, с. 56]; Т. В. Машаровой и Е. Л. Сырцовой [12]; Э. К. Никитиной и О. А. Любченко [13]; И. В. Вачкова, С. Н. Вачковой и М. В. Воропаева [5]; К. А. Баранникова, С. М. Лесина, С. Н. Вачковой, Р. С. Сулейманова, Р. Б. Куприянова [21]; О. В. Масловой, Д. А. Шляхты, М. С. Яницкого [24, р. 66]; G. Ferreira, M. Gastal, M. Avanzi [22]; M. Ferrero, E. Konstantinidis, M. Vadillo [23] и других. Социологами, психологами и педагогами раскрывается идея о том, что изучение ценностей личности в аспекте педагогики и образования позволит спроектировать эффективные современные технологии отбора содержания актуальных знаний, создания образовательных программ, организации образовательной практики, в первую очередь, обучения педагогов. На основании современного состояния исследования проблемы можно констатировать, что острый вопрос о связи ценностей с мотивами выбора профессии в структуре личности педагога требует дополнительного изучения.

Теоретическое обоснование проблемы позволило спланировать опытную работу. Эмпирическое исследование было проведено в 2019 году в Московском городском педагогическом университете. Реализация эмпирических задач осуществлялась с помощью трёх взаимодополняющих методик. Методики предъявлялись поочерёдно: сначала проективные - анкета и эссе; затем стандартизованные - опросники индивидуально каждому испытуемому. Выборка: 46 студентов (девушек) первого курса педагогического направления обучения в возрасте 17-19 лет.

\section{Исследование мотивов профессионального выбора и ценностных ориентаций студентов педагогического университета}

Первый этап эмпирической работы охватывал изучение мотивов профессионального выбора. Он включал сбор и анализ результатов анкеты и эссе. Предварительные результаты, полученные на первом этапе, позволили определить критерии и показатели мотивов выбора профессии студентами педагогического направления обучения. Подсчёт результатов проводился суммированием количества одинаковых ответов одного респондента на аналогичные по сути, но разные по форме вопросы. Кроме того, учитывалось, как часто разные респонденты дают идентичные ответы на вопросы. 
Анализ результатов позволил определить критерии и показатели:

1) критерий направленности на взаимодействие (показатели: любовь к детям; желание помогать; желание работать с детьми; интерес к детям);

2) критерий направленности на себя (показатели: стремление к саморазвитию, самореализации; возможность изучать то, что интересно; творческая самореализация; демонстрация своих творческих способностей; профессиональный успех; желание «разобраться в себе»; инфантильность, например, желание «побыть ребёнком», погрузиться в детство, проводить с детьми время);

3) критерий осознанности выбора профессии (показатели: интерес к работе педагога; наличие знаний о педагогической профессии; понимание требований к педагогу и своего соответствия им; случайность профессионального выбора или выбор под влиянием внешних обстоятельств, например, подошли результаты ЕГЭ, университет находится рядом с домом, поступила вместе с подругой);

4) социальный критерий (показатели: продолжение педагогической династии; по примеру авторитетного взрослого человека; по совету близких людей);

5) культурный критерий (показатели: после прочитанной книги про педагогов; после просмотренного фильма про педагогов; под влиянием педагогических сайтов в интернете);

6) гендерный критерий (показатели: педагог - «женская» профессия; профессиональные знания помогут мне в жизни, то есть в создании благополучной семьи и воспитании своих детей);

7) финансовый критерий (показатели: зарплата педагога адекватна затраченным усилиям и хорошим условиям труда; у педагогов оплачиваемый короткий рабочий день; оплачиваемые дни по болезни; большой оплачиваемый отпуск).

Количественное распределение по показателям высказываний респондентов в проективных методиках (анкете и эссе) представлено на Рисунке 3.

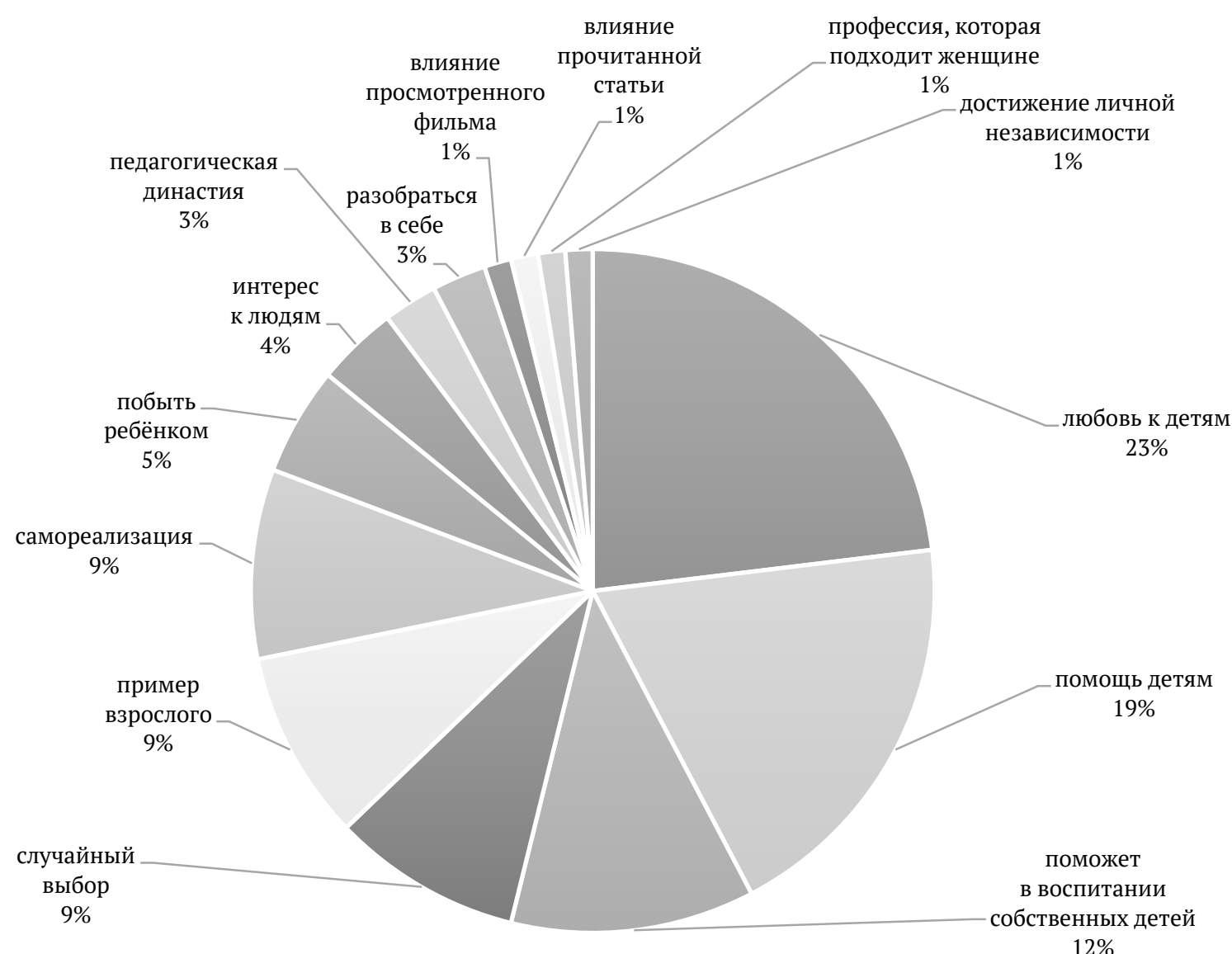

Рисунок 3. Количественное соотношение показателей мотивов профессионального выбора в высказываниях респондентов по материалам анкеты и эссе

По результатам анализа анкет и эссе наиболее распространёнными ответами на вопрос «Почему я выбрала педагогическую профессию?» были: любовь к детям, интерес к профессии педагога, стремление помогать другим, направленность на взаимодействие с взрослыми людьми и детьми, саморазвитие и самореализация, потребность разобраться в себе и в других людях. Так в исследовании были получены эмпирические данные о мотивах профессионального выбора респондентов.

Второй этап эмпирического исследования заключался в проведении стандартизованных методик: опросников Рокича, Шварца и Д. А. Леонтьева. 


\section{Выявление связи ценностных ориентаций личности и мотивов выбора профессии в структуре личности студентов педагогического университета}

Для этого сводные результаты исследования были подвергнуты процедуре кросстабуляции с использованием коэффициента корреляции Спирмена. Полученные числовые значения коэффициента корреляции между показателями, отражающими мотивы профессионального выбора и ценностные ориентации личности, были разделены на три уровня:

1) высокий уровень коэффициента корреляции - значения 0,5 и выше;

2) средний уровень коэффициента корреляции - значения от 0,3 до 0,5;

3) низкий уровень коэффициента корреляции - значения от 0,2 до 0,3.

Числовые значения коэффициента корреляции менее 0,2 рассматривались как настолько низкие, что ими можно пренебречь. При анализе результатов эти числовые значения не учитывались.

Максимальные показатели коэффициента корреляции личностных ценностей и мотивов профессионального выбора были получены по показателям, представленным на Рисунке 4.

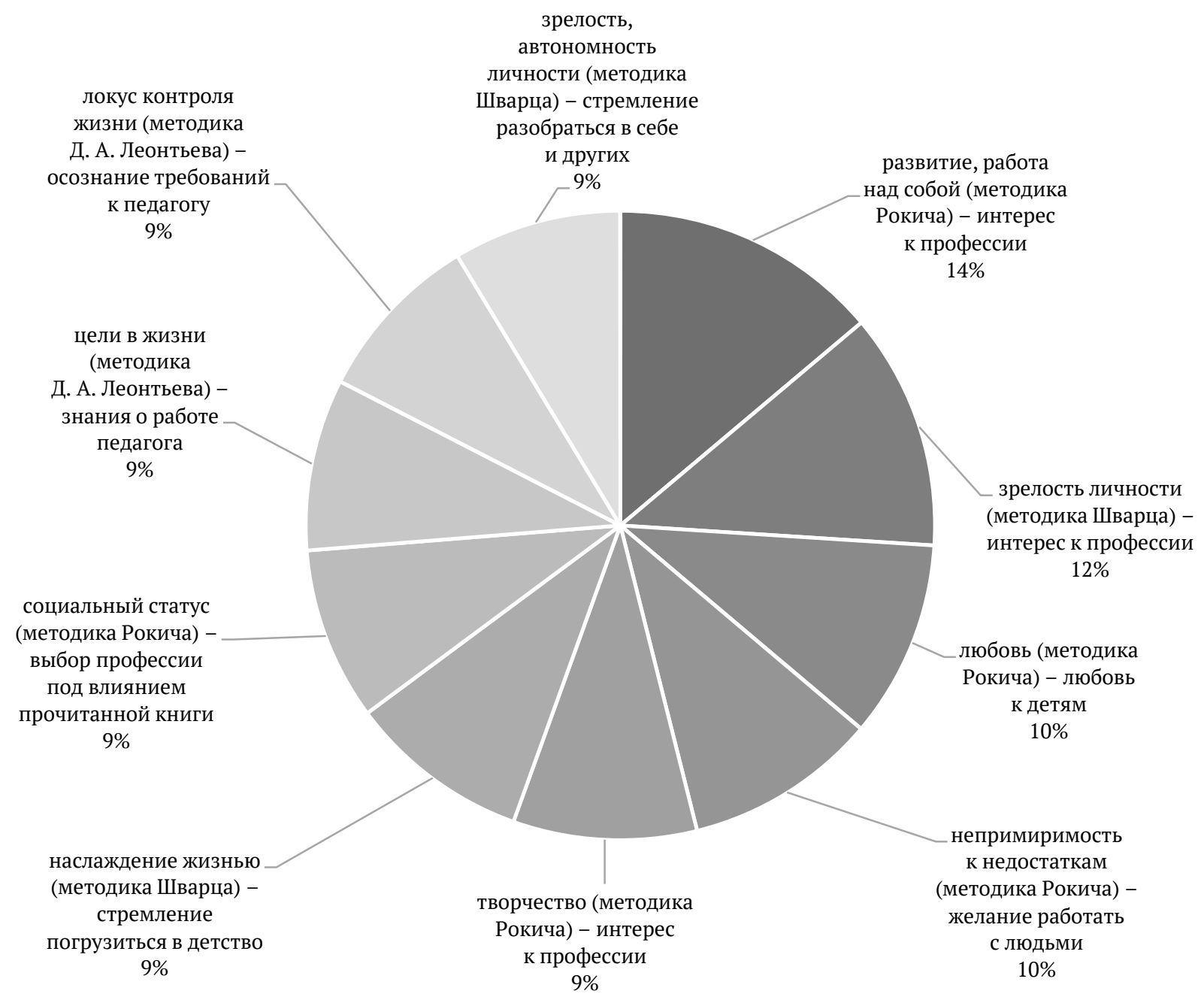

Рисунок 4. Высокие показатели корреляции личностных ценностей и мотивов выбора профессии студентами педагогического направления обучения

Максимальный показатель коэффициента корреляции $(0,803)$ позволяет отметить соответствие ценности развития, работы над собой, постоянного самосовершенствования интересу к профессии, профессиональной деятельности в качестве значимого мотива личности.

Интерес к профессии, к профессиональной деятельности как мотив выбора профессии соотносится с ценностью зрелости, автономности и признания собственной индивидуальности с коэффициентом корреляции 0,704. Как было сказано ранее, осознанный личностный выбор, в том числе выбор профессии, служит одним из показателей зрелости личности. 
Характерно соотнесение категории любовь (методика Рокича) ответу о профессиональном выборе, обусловленном любовью к детям. Коэффициент корреляции 0,588, представляет способность к любви, её значимость, как интегративное качество личности и смысл человеческой жизни.

Корреляция непримиримости к недостаткам в себе и других с желанием, стремлением работать с людьми, в том числе с детьми, в ответах респондентов в равной степени присутствуют оба варианта, с коэффициентом корреляции 0,574 позволяет интерпретировать полученные данные в контексте того, что работа педагога направлена на качественное позитивное изменение другого человека.

Согласованность категорий интереса к профессии с творчеством с коэффициентом корреляции 0,547 раскрывает суть педагогической профессии, которая иногда рассматривается как искусство. Действительно, ребёнок - активный субъект педагогического процесса, сложен, непостоянен, он всегда разный. Педагогический процесс во всех мельчайших деталях - это всегда новые обстоятельства, каждый раз иные ситуации, в которых творчество - один из необходимых компонентов профессиональной деятельности. Помимо этого, в работе с детьми педагогу в рамках должностных обязанностей необходимо включаться в разнообразные виды совместной деятельности, в том числе игровую, художественно-изобразительную, музыкальную, конструктивную и другие, предполагающие творческий подход в работе. Выбор профессии на основе понимания педагогической профессии как многогранной деятельности, в которой раскрывается творческий потенциал не только ребёнка, но и самого педагога, звучит также в высказываниях испытуемых в анкетах и эссе: «Я поняла, что не хочу просто убивать время на работе, а хочу чего-то более интересного... Тут есть возможность показать себя в творческой деятельности, мне это нравится. На работе будет трудно, но зато не скучно».

Интересны, на наш взгляд, результаты корреляции категорий «наслаждение жизнью» и «стремление погрузиться в детство» с коэффициентом корреляции 0,541. Детство может рассматриваться как счастливый, беззаботный период жизни, время наслаждений и удовольствий. Доказательством того, что молодые люди видят в выбранной профессии возможность продлить собственное детство, окунуться в его беззаботное время, служат примеры из анкет и эссе: «Я ожидаю от профессии возвращения в своё покинутое детство»; «Я выбрала педагогическую профессию, потому что мне нравится самой быть ребёнком»; «Я отлично понимаю детей, ведь в душе я сама ребёнок».

Описывая свой будущий рабочий день, респонденты указывают: «На работе буду много играть с детьми, читать с ними интересные книги». Некоторые упоминают конкретные привлекательные для них игры, в том числе компьютерные, и игрушки (конструкторы, куклы) как обязательную часть профессии: «У меня на работе будет сухой бассейн». Многие испытуемые в качестве служебных обязанностей называют режимные моменты: «Погуляли, потом - обед, сон, потом - полдник». Стремление вернуться в детство, стать снова ребёнком можно интерпретировать как тенденцию к инфантилизму.

Показатель коэффициента корреляции 0,515 в категории социального статуса (методика Шварца) с выбором профессии под влиянием прочитанной книги мы связываем с тем фактом, что большинство респондентов называют в качестве литературного произведения, повлиявшего на профессиональный выбор, книгу Ш. А. Амонашвили «Здравствуйте, дети!». В данной связи можно предположить, что значительную роль здесь играет фигура талантливого педагога, авторитетного взрослого, его значимое, высокое положение среди учеников. Такого рода образец профессионала повышает не только личный статус человека, выбравшего педагогический труд делом своей жизни, но и статус самой профессии. Проиллюстрируем примером из эссе: «Особенно интересна для меня была книга Амонашвили “Здравствуйте, дети!”. Я бы рекомендовала её читать, так как лично для меня она была очень познавательна и интересна, эта книга многому меня научила».

Корреляция категорий целей в жизни по методике Смысложизненных ориентаций Д. А. Леонтьева и объективности представлений о сути и содержании профессиональной деятельности с коэффициентом 0,511 может быть объяснена осмысленностью профессионального выбора как значимой части жизни, видением себя в будущем.

В соотнесении категорий локуса контроля жизни и управляемости жизни убеждения в том, что человеку дано контролировать свою жизнь по методике Смысложизненных ориентаций Д. А. Леонтьева, с пониманием требований к педагогу с коэффициентом корреляции 0,509 видна та же составляющая осознанности, что и в предыдущем случае. Понимание будущих условий, обстоятельств жизни, определяет активное управление собственной деятельностью, в том числе профессиональной, например: «Педагог - сложная профессия, потому что это большая ответственность перед детьми и родителями».

Интерпретация корреляции категорий зрелости, автономности, признания собственной индивидуальности с мотивом стремления решить собственные проблемы, «разобраться в себе» и в других людях с коэффициентом корреляции 0,502 очевидна. Личность развивается, проходя через определённые этапы жизненного пути, например, профессиональное самоопределение. Человек последовательно решает задачи этого этапа, преодолевает возникшие трудности и противоречия. Это - путь становления зрелой личности.

Зафиксированная корреляция позволяет отметить неравномерное распределение значимых коэффициентов высокого, среднего и низкого уровня в значении от 0,2 до 1 и незначимых коэффициентов с показателями менее 0,2, которыми можно пренебречь. Анализ сопряжённости категорий, отражающей высокий коэффициент соотнесения, был представлен выше. Наиболее «нагруженными» средними и низкими значениями являются показатели критерия направленности на взаимодействие с людьми: любовь к людям, детям; стремление оказать помощь людям, детям; желание работать с людьми, детьми. В критерии направленности на себя 
наибольшее количество средних и низких коэффициентов корреляции представлено по показателям: стремление к саморазвитию, самореализации; реализация собственного творческого потенциала, демонстрация своих творческих возможностей; желание решить собственные психологические проблемы, «разобраться в себе» и в людях; стремление «побыть ребёнком», погрузиться в детство, проводить время совместно с детьми.

Применительно к критерию осознанности профессионального выбора можно говорить о большей выраженности значений коэффициента корреляции по показателям: интерес к профессии с представлениями о содержании профессиональной деятельности.

В меньшей степени загруженными значимыми коэффициентами - высоким, средним и низким - являются гендерный и финансовый критерии. Гендерный критерий мотивации профессионального выбора отражает социальную роль женщины, например: «Педагогическая профессия подходит женщине», «Знания, полученные мной за время учёбы, пригодятся для воспитания своего ребёнка», «Полученные знания помогут мне создать счастливую семью». Финансовый критерий включает показатели заработной платы, адекватной приложенным усилиям, и подходящие условия работы: «Я буду получать деньги за дело, которое мне нравится»; «Каждый день, вставая утром, я буду радоваться тому, что иду на любимую работу. И, плюс, мне за неё ещё и платить будут». Значения коэффициентов, отражающих данные критерии, оказались менее значимыми, чем те, что составляли низкий уровень. Это позволяет сделать вывод об отсутствии соотнесения данных мотивов с ценностными ориентациями личности респондентов.

Анализ распределения значений коэффициентов корреляции по шкалам, отражающим ценностные ориентации личности в соотнесении с мотивами профессионального выбора, также позволяет судить о разной степени сопряжённости категорий. При этом количественное распределение средних и низких значений коэффициентов сопряжённости по шкалам опросников можно охарактеризовать как равномерное.

В то же время при соотнесении ценностных ориентаций личности и мотивации профессионального выбора отмечается большее количество средних значений по шкалам, которые представлены на Рисунке 5.

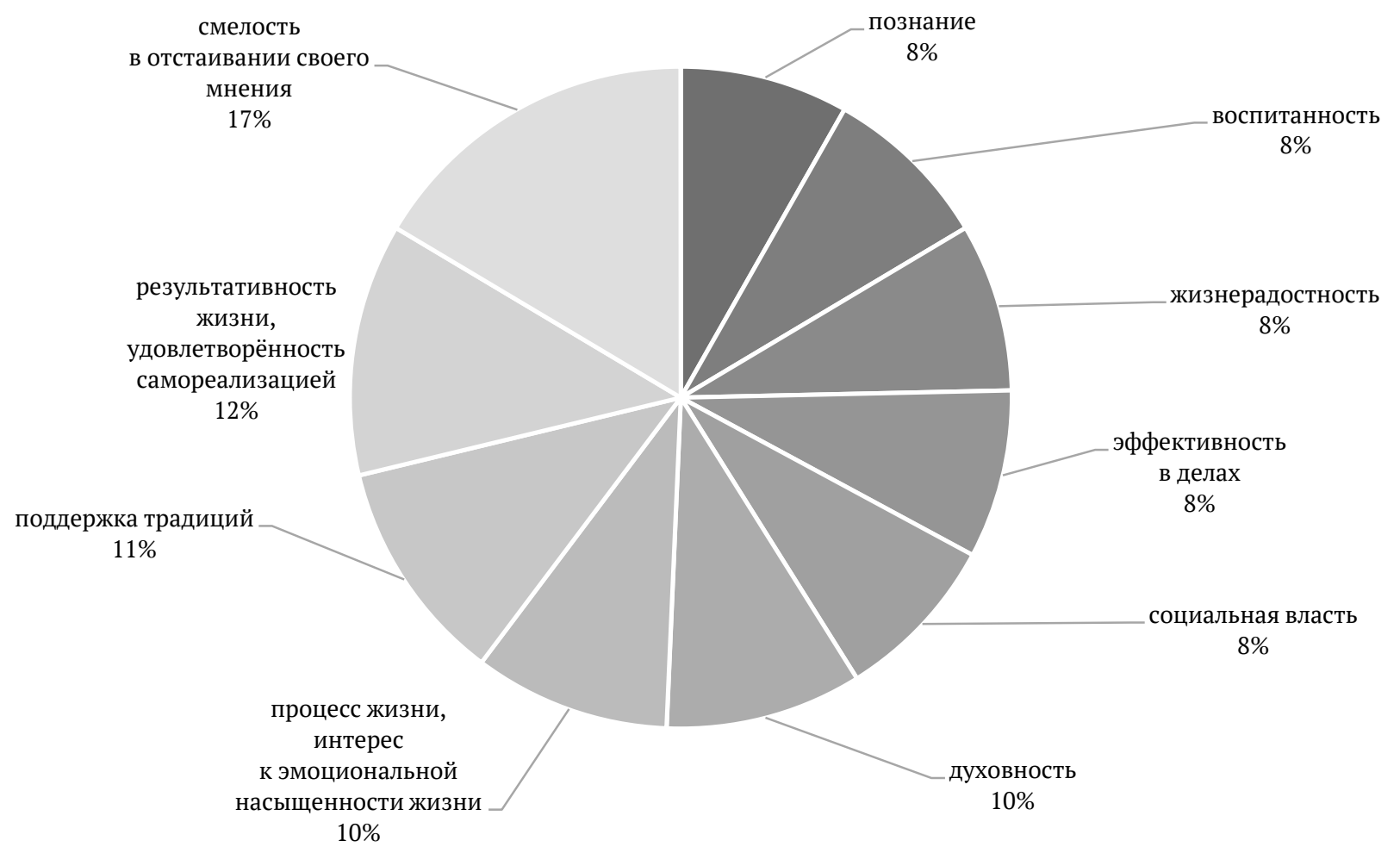

Рисунок 5. Средние значения корреляции ценностей личности и мотивов выбора профессии студентами педагогического направления обучения

На рисунке видно, что мотивы профессионального выбора респондентов коррелируют с личностными ценностями: смелости в отстаивании своего мнения, результативности жизни и удовлетворённости самореализацией, эффективности в делах, социальной власти, познания, воспитанности, духовности, поддержки традиций, интереса к эмоциональной насыщенности жизни, жизнерадостности. Все перечисленные ценности нашли отражение в ответах респондентов на вопросы анкеты и в текстах эссе.

Так, смелость в отстаивании своего мнения отразилась в следующих высказываниях: «Когда я говорила своим учителям и друзьям, что хочу быть педагогом, они мне говорили, что эта профессия не востребована, всячески пытались меня отговорить. Я, конечно же, выслушивала их мнение, но, прежде всего, стояла на своём и защищала свои интересы. Я понимала, что моя будущая профессия - это, прежде всего, выбор для меня самой, а не для всех тех людей, которые меня окружают. Я шла к своей цели». 
Результативность жизни и удовлетворённость самореализацией, наряду с эффективностью в делах, могут отражать новый жизненный статус респондентов - студента университета: «Дети учат нестандартно мыслить... Дают возможность расти вместе с ними, реализовать себя в профессии».

Корреляция ценности социальной власти с мотивацией профессионального выбора характерна для педагога, в деятельность которого включены планирование, организация, контроль и оценка образовательного процесса и деятельности детей. Стремление к власти может рассматриваться как мотив выбора профессии на основании следующих высказываний респондентов: «У меня есть жизненный стержень, характер. Есть чётко сформулированные нравственные принципы».

Ценность воспитанности является одной из главных для профессии педагога. Воспитанность близка интеллигентности, такту, деликатности, которые определяют профессиональный облик педагога, что находит отражение в эссе испытуемых: «В лагере, где я работала помощником наставника, мне было нелегко стать авторитетом для них. Всем известно, как легко можно обидеть ребёнка».

Духовность и поддержка традиций в значительной мере отражают представления об учителе, педагоге, сложившиеся в культуре. Это же подтверждают респонденты: «Быть педагогом трудно. Для этого нужно иметь терпение, милосердие, любовь»; «Быть педагогом тяжело. Прежде всего, нужно отдавать всего себя, не щадя. И так каждый день, каждую минуту».

Корреляция интереса к эмоциональной насыщенности жизни, жизнерадостности с мотивацией профессионального выбора также может быть интерпретирована как неслучайная. К числу особенностей личности педагога, определяющих его профессиональную пригодность, обычно относят эмпатию, оптимизм и чувство юмора. Человеку, не обладающему подобными качествами, будет сложно привить их детям. О важности наличия у педагога эмоционального отклика, оптимизма и жизнерадостности говорят респонденты: «Я выбрала профессию педагога. Как бы банально это ни звучало, она... позволяет всю жизнь сохранять жизнерадостность, оптимистичность, энергичность».

Низкий, но значимый коэффициент корреляции $(0,2-0,3)$ ценностных ориентаций личности с мотивами профессионального выбора интерпретируется нами как неслучайный. Низкий коэффициент корреляции прослеживается по шкалам ценностей: любовь и счастливая семейная жизнь, наличие хороших и верных друзей, счастье других, терпимость, ответственность и твёрдая воля, конформизм как направленность на сдерживание социально неодобряемых склонностей представляют собой значимые позиции в профессии педагога, характеризуют одновременно гуманистическую направленность личности и целенаправленность в профессии. Пример из эссе подтверждает это: «Быть педагогом дано не каждому, нужно терпение, упорство, душевная теплота».

Стимуляция как стремление к разнообразию, новизне и глубоким переживаниям, возможно, свойственна не только особенностям личности, но и возрасту испытуемых. Это видно из ответов испытуемых на вопросы анкеты о причинах выбора профессии, например: «Мне очень понравилось работать с детьми. Каждый день получала заряд бодрости, энергии, новые впечатления. Как может быть иначе, если работаешь с детьми?».

Раскрыв основные соотношения исследуемых категорий и представленность коэффициентов сопряжения в них, перейдём к выводам.

\section{Заключение}

Проведённое эмпирическое исследование позволило изучить мотивационно-личностную сферу личности студентов педагогического направления в ситуации профессионального выбора. Собранные данные подтвердили предположение о том, что ценности личности обуславливают мотивы выбора педагогической профессии. Была достигнута цель исследования - выявлена взаимосвязь ценностей личности и мотивов выбора профессии у студентов, обучающихся по педагогическому направлению в Московском городском университете. Последовательное решение задач исследования позволило, во-первых, проанализировать теоретические подходы к изучению связей личностных ценностей субъекта с его мотивацией и на их основе спланировать эмпирическую работу. Во-вторых, с помощью взаимодополняющих проективных и стандартизованных методик были исследованы мотивы профессионального выбора и ценностные ориентации студентов педагогического университета. В-третьих, была выявлена взаимосвязь ценностных ориентаций личности и мотивов выбора профессии в структуре личности студентов педагогического университета.

Величина значений коэффициентов корреляции показывает степень осознанности выбора профессии и самоидентификацию с профессией будущих педагогов. Максимальная степень корреляции мотивов выбора педагогической профессии и ценностей личности выявлена в направленности на взаимодействие с людьми и направленности на себя, в осознанности профессионального выбора, в социальной и культурной обусловленности профессионального выбора.

Высокий коэффициент корреляции ценностей личности и мотивов профессионального выбора прослеживался по категориям саморазвития и самосовершенствования, зрелости, стремления разобраться в себе и в людях, возможности заниматься творчеством с категорией интереса к педагогической профессии. Кроме того, высокий коэффициент корреляции был выявлен по категориям непримиримости к недостаткам в себе и других и желания работать с детьми; наслаждения жизнью и стремления погрузиться в детство.

Основанием соотнесения категорий целей жизни и представлений о профессиональной деятельности, локуса контроля жизни и знания требований, предъявляемых профессионалу, служит осознанность профессионального выбора. Сопряжённость разных трактовок категории любви к человеку позволяет охарактеризовать её как интегративное свойство ценностных ориентаций личности и мотивации профессионального выбора. 
Исследованная проблема составляет одну из многих, относящихся к изучению жизненного пути человека, включённости личности в разные виды деятельности. Ключевой характеристикой современного мира, жизни человека является неопределённость, которая требует от личности адекватных откликов и конкретных действий. Проведённое эмпирическое исследование трактует поведение молодых людей в обстоятельствах профессионального выбора. В основу исследования было заложено аксиологическое знание в психологии. По нашему мнению, использованные методы и полученные результаты предоставляют новые возможности для изучения субъектности личности, свободы выбора и ответственности за него, роли личностных ценностей в принятии решений. Материалы исследования могут быть использованы при проектировании образовательной работы со студентами бакалавриата.

\section{Список источников}

1. Ананьев Б. Г. О проблемах современного человекознания [Электронный ресурс] / АН СССР, Ин-т психологии. М.: Наука, 1977. 379 с. URL: http://elib.gnpbu.ru/text/ananyev_o-problemah-sovremennogo_1977/ (дата обращения: 09.11.2020).

2. Асмолов А. Г. Образование как ценностное полагание: диалог между педагогикой сотрудничества и культурно-исторической психологией // Народное образование. 2018. № 5. С. 48-53.

3. Бим-Бад Б. М. Образование как развитие природных дарований: к постановке вопроса // Известия Российской академии образования. 2019. № 1 (49). С. 56-64.

4. Будинайте Г. Л., Корнилова Т. В. Личностные ценности и личностные предпосылки субъекта // Вопросы психологии. 2013. Т. 14. № 5. С. 99-106.

5. Вачков И. В., Вачкова С. Н., Воропаев М. В. Представления родителей о качестве образования детей в мегаполисе и их установки в отношении родительского контроля // Психологическая наука и образование. 2019. T. 24. № 3. С. 19-31.

6. Выготский Л. С. Сознание как проблема психологии поведения // Выготский Л. С. Психология человека. М.: Смысл; Эксмо, 2005. С. 11-21.

7. Гавров С. Н., Никандров Н. Д. Образование в процессе социализации личности // Вестник университета Российской академии образования. 2008. № 5 (43). С. 21-30.

8. Деятельностный подход в образовании: монография: в 2-х кн. / сост. В. А. Львовский. М.: Авторский клуб, 2018. Кн. 1. 360 с.

9. Иванников В. А., Гусев А. Н., Барабанов Д. Д. Связь осмысленности жизни и способа контроля за действием с самооценками студентами волевых качеств // Вестник Московского университета. Серия 14. Психология. 2019. № 2. С. 27-44.

10. Леонтьев А. Н. Деятельность. Сознание. Личность [Электронный ресурс]. М.: Политиздат, 1975. URL: http://www.psy.msu.ru/people/leontiev/dsl/index.html (дата обращения: 08.11.2020).

11. Леонтьев Д. А. Три мишени: личностный потенциал - зачем, что и как? // Образовательная политика. 2019. № 3 (79). С. 10-16.

12. Машарова Т. В., Сырцова Е. Л. Интеллигентность как ведущее качество будущего специалиста. Киров: Изд-во ВятГГУ, 2006. 99 с.

13. Никитина Э. К., Любченко О. А. Модель внедрения креативных профессиональных и коммерчески значимых инициатив студентов и молодых учителей // Современные проблемы науки и образования. 2015. № 4. С. 185-193.

14. Подольский А. И., Идобаева О. A. QUO VADUS? Траектории ценностно-мотивационного развития современной российской молодёжи // Вопросы психологии. 2019. № 2. С. 45-58.

15. Рубинштейн С. Л. Человек и мир. СПб.: Питер, 2012. 224 с.

16. Слободчиков В. И. Мир меняют не политики, а учителя // Профилактика зависимостей. 2019. № 1 (17). С. 1-3.

17. Собкин В. С., Андреева А. И., Рзаева Ф. Р. Научный сотрудник в сфере образования: ценностно-мотивационные особенности профессиональной деятельности // Вопросы психологии. 2018. № 2. С. 88-99.

18. Фельдштейн Д. И. Проблемы психолого-педагогических наук в пространственно-временной ситуации XXI века: вызовы информационной эпохи // Вопросы психологии. 2013. № 1. С. 46-65.

19. Фонарёв А. Р. Развитие личности в процессе профессионализации // Вопросы психологии. 2004. № 6. С. 54-62.

20. Ядов В. А. Диспозиционная система как целостная структура реального поведения // Ядов В. А. Саморегуляция и прогнозирование социального поведения личности: диспозиционная концепция. М.: Центр социального прогнозирования и маркетинга, 2013. С. 203-224.

21. Barannikov K. A., Lesin S. M., Vachkova S. N., Suleimanov R. S., Kupriyanov R. B. Application of educational data analysis methods in the evaluation of lesson scenarios in the Moscow electronic school // Revista Inclusiones. 2020. Vol. 7. № S3-3. P. 1-8.

22. Ferreira G., Gastal M., Avanzi M. Em busca de vestígios e sinais de um professor em formação experiencial: O que revelam suas narrativas autobiográficas? Looking for impressions and signs of a teacher in formation through experience: What shows your autobiographical narratives? // Olhares \& Trilhas. 2020. Vol. 22. № 2. P. 183-202. DOI: 10.14393/OT2020v22.n.2.55629. 
23. Ferrero M., Konstantinidis E., Vadillo M. An Attempt to Correct Erroneous Ideas among Teacher Education Students: The Effectiveness of Refutation Texts // Frontiers in Psychology. 2020. Vol. 11. P. 1-7. DOI: 10.3389/ fpsyg.2020.577738.

24. Maslova O. V., Shlyakhta D. A., Yanitskiy M. S. Schwartz value clusters in modern university students // Behavioral Sciences. 2020. Vol. 10. Issue 3. P. 66-72.

25. Moate J., Ruohotie-Lyhty M. Identity and Agency Development in a CLIL-based Teacher Education Program // Journal for the Psychology of Language Learning. 2020. № 2 (2). P. 92-106.

26. Polkovnikova N. B. Influence of adults value orientations on the five-years old children valuable elements // LAssociation 1901 SEPIKE. 2013. № 3. P. 41-44.

27. Stellmacher A., Ohlemann S., Pfetsch J., Ittel A. Pre-Service Teacher Career Choice Motivation: A Comparison of Vocational Education and Training Teachers and Comprehensive School Teachers in Germany // International Journal for Research in Vocational Education and Training. 2020. Vol. 7. Iss. 2. P. 214-236. DOI: 10.13152/IJRVET.7.2.5.

\section{Информация об авторах | Author information}

RU Полковникова Наталья Борисовна ${ }^{1}$, к. пед. н., доц.

${ }^{1}$ Московский городской педагогический университет

EN Polkovnikova Natalia Borisovna ${ }^{1}, \mathrm{PhD}$

${ }^{1}$ Moscow City University

${ }^{1}$ polkovnikovanb@mgpu.ru

Информация о статье | About this article

Дата поступления рукописи (received): 02.11.2020; опубликовано (published): 30.12.2020.

Ключевые слова (keywords): выбор профессии; ценности личности; образование студентов; подготовка к педагогической профессии; choosing profession; person's values; education of students; teacher training. 